\title{
Working Together to Carry Water: Research Ethics when One of Two Parents is Indigenous
}

\author{
Will Tuladhar-Douglas ${ }^{1^{*}}$ and Bhavana Tuladhar-Douglas ${ }^{1}$ \\ ${ }^{1}$ Situgyan Consulting Limited, Aberdeen, United Kingdom. \\ *will@tending.to
}

\begin{abstract}
What are the ethical challenges and opportunities for a household where one parent is Indigenous and the other not? This article uses events from one family history to explore how social and political contexts in both the country of Indigenous origin and the country of residence drive research ethics. It argues that research ethics for such parents should be framed within the ethics of transmitting Indigenous culture for the family within a transnational Indigenous lineage.

Received July 24, 2017

OPEN ӘACCESS

Accepted November 24, 2017

DOI 10.14237/ebl.9.1.2018.1064

Keywords Newar, Indigenous, Research ethics, Transnational, Kinship, Marriage

Copyright (c) 2018 by the author(s); licensee Society of Ethnobiology. This is an open-access article distributed under the terms of the Creative Commons Attribution-NonCommercial 4.0 International Public License (https://creativecommons.org/licenses/by-nc/4.0), which permits non-commercial use, distribution, and reproduction in any medium, provided the original author and source are credited.
\end{abstract}

This essay began with an email exchange. Letitia McCune wrote to ask if we had any opinions on a question that had been raised during a discussion of research ethics in ethnobotany. The question was, If you marry into a traditional culture from another country and traditional knowledge is passed down to you as part of lineage rules of culture, then what permits/agreements do you need in order to use that information?'. This question seemed to us to convey troubling misunderstandings of who Indigenous and traditional communities are and where they live, of the moral qualities of kinship, and of the purpose of research ethics, and therefore to require a response that was more than a theoretical argument.

Our initial answer at that stage, just a long email, was framed as a series of examples drawn from our experiences, each intended to make the point that, while outside researchers may make do with permits and agreements, families are subject to a wholly different moral calculus based on kinship obligations. Letitia McCune and Cissy Fowler encouraged us to transform that email into a full-length essay. We have carried this question with us through a year of conversations and writing about cultural transmission and ethics within an extended family across multiple generations.

The resulting essay still has a core structure of autobiographical anecdotes, extended by insights from wiser friends and buttressed with theory and history where appropriate. The examples we have chosen are not only cautionary, though many of them are. Rather in the way Austin used infelicities to expound a theory of language (Austin 1975), these episodes use the negative space of difficulties to show what does work, or perhaps to show a work in progress. What remains might be called the play of kinship.

The transmission of culture across our tangled node in this particular extended family is sometimes transformed into academic practice, sometimes into activism and advocacy, and often is just about getting along with grandparents, cousins, children, gardens, dogs, and local deities. It would be possible to analyze our cheerful predicament through positionality (e.g., Ahmad 2004), but we feel that positionality is not an adequate framework either to engage the specific challenges of Indigenous relatedness, nor the lack of moral seriousness apparent in the original question. There are ancestors and children here! Kinship has long been theorized as a structuring principle by anthropologists, but here we would like to foreground kinship as a basis for research ethics. Inevitably this connects to larger discussions around kinship ecology (Kimmerer 2011) and place (Basso 1996; Ingold 2000), but for now our goals are more modest ${ }^{1}$. We hope to confront prejudice, exploitation, and 
commodification. We also try to show how much fun we have as a family within a kin network-the extraordinary support we exchange even with quite distant relatives, and the compassion, wisdom, love, and hope that we have been so fortunate to enjoy. We would like to acknowledge the constructive and supportive feedback we have had at several stages, from our families, from Letitia McCune and Cissy Fowler, from colleagues at the 2017 CSVPA workshop in Vilm, and from two anonymous peer reviewers.

Our particular household was created when Bhavana, an Indigenous Newar woman, married Will, a Californian who had studied Newari for many years. As is often the case for marriages that link cultural traditions, we married twice: once in a legal ceremony in Oxford, a ritual that granted political and legal status; and once in a far more elaborate ceremony attended by relatives from both side at the Vajrayogini shrine in Pharping, Nepal, that actually created kinship. Not long after, we two moved to Scotland when Will got a post in anthropology of religions at the University of Aberdeen. Our three children have been born and grown up mostly in Northeast Scotland but sometimes, when we were undertaking extended research, in Nepal Mandala, the traditional Newar domain of central Nepal. Frequent videochats between our kitchen in Aberdeen and the kitchen in Pharping exchange recipes for food, remedies for illness, and ordinary neighborhood news.

Birthdays in our family take a long time. To begin with, every person has two possible birthdays: the tithi, determined by traditional Newar astrology, or their Western calendar birthday. Depending on the offset between the lunisolar calendar in Nepal and the Western calendar, these can be almost a month apart-but we decided, some years ago, just to celebrate one birthday for each person even though we do calculate the exact date for both. Then there are the rituals. In California and in Scotland, one must have a cake which is decorated with candles, and the flames on these candles actually have to be blown out with the mouth. Newars find the prospect of polluting any flame (pure) with exhalation (impure) deeply distasteful, but this has become our single permitted family exception to that rule. There is also a requirement to give quite a few presents to the person having a birthday, and they may well want to have some sort of social event such as going to a 'party palace' with their friends-this can involve long negotiations with other parents. The Newar rituals are simpler: the eldest woman (nakhi), after she has performed all the usual morning rituals as well as a Ganadyah worship, assists the child in performing a simple pīja (worship) of Ganadyah, the remover of obstacles. Then she pours tahla (sesame balls) over the child's head, and presents them with yoghurt, a dried fish, a bit of ayläh (brandy), an egg, and a flower plus $£ 1.01$ in coins and a gwe (the nut of Areca catechu L.) on a new piece of clothing ${ }^{2}$. By choice, we don't eat fish or drink brandy in our house, so the dried fish has been replaced by buttered toast cut in the shape of a fish and the brandy by that week's exciting fizzy drink; and because ours is only a small household, both parents help with the ritual, though properly it is women's business. Certain birthdays do need longer rituals and more specially prepared items, but those are relatively rare. It goes without saying that the parents must fast from waking until all the rituals are finished, though a cup of coffee does occasionally slip in. Those Western rituals require much more complicated food: the baking of a cake, which can take hours depending on which cake is wanted, and a special dinner-and between the birthday cake, the tahla, the puijā, the party palace, the presents....it can be a bit overwhelming. When we are in Nepal, the situation is reversed. There are no party palaces in our town, and the first bakery with ready-made cakes only opened a few months ago. However, it is necessary to carry out a more complete set of Newar rituals with the help of various members of the extended family, many of whom then walk to various shrines with appropriate offering plates. A few years ago, we two parents said that we were just not going to do all the rituals. The children had none of it. They made it clear that every single one of those rituals are part of who they are, no one of them is optional, and it's not a proper birthday in our family without all the fuss, bother, and rituals ${ }^{3}$. Given the challenges that our children face every day growing up Tulādhars in Scotland, it seems to us that they deserve all the support and special rituals we can give them, even if it means a few exhausting days for us.

Conducting research as us is also like that. Bhavana is a Nardevī Tulādhar, an Indigenous Newar; Will was born in California, and his sister describes him as 'having lived in Asia for half his life'. We live and work in Scotland, and nothing became easiereither in research or in ordinary life-because Will married into Bhavana's family, or because Bhavana took on a husband who wasn't Newar, or because we 
live in Scotland. While it might seem as though marrying a foreign anthropologist could help transform an Indigenous person into an 'anthropologist,' or that marrying in grants a researcher some kind of special access to Indigenous knowledge without the onus of seeking permission, in fact the opposite is true. Rather than a license to exploit, marriage across the line between Indigenous and outsider is a constraining entanglement. At its best, it is an agreement to abide by the highest standards that either side brings to the marriage; but there are also risks and attacks. Intolerance is a feature of every community. Our particular family is a site of tremendous creativity, but it is also a point of vulnerability and many of the choices we have made are, of necessity, defensive: we have learned to protect our children, ourselves, our extended family, and our informants from what might otherwise be ordinary interactions with students, colleagues, universities, and governments. In this essay, we will explore some of the political contexts and ethical challenges that confront a family where both parents conduct research together but one has married into the other's Indigenous community. Rather than proceeding from abstract principles we will use a few stories from our mutual history (with names masked or changed appropriately) to illustrate the challenges and opportunities that we encounter and how we approach them.

\section{Newars}

First, though, let us clarify a few issues around kinship and terminology. Newars are one of the more confusing Indigenous communities for folk who expect all Indigenous communities to be small-scale hunter-gatherers. They are an ancient, urban, literate, and fragmented community that was in its origins highly diverse (Gaenszle et al. 2016:264-266). Newar civilization had its center in the great city-states of central Nepal, but extended across a wider agricultural hinterland and included exclaves in Asian market cities such as Lhasa, Shigatse, and Patna. The Kathmandu Valley and its environs hosted a complex society that was united by a common language and ritual system, though never politically united. It constantly attracted new immigrant clans. Newars themselves recognize that many lineages are exogenous; some Buddhist priestly families living in the great monasteries of Kathmandu or Lalitpur point to their origins in eleventh century Bengal, when refugees from the great monastic universities fled to the relative shelter of the Kathmandu Valley. Other groups, such as Jyapu or Balami, regard themselves and are regarded by other Newars as the original inhabitants of the Valley. Still others, such as the longsettled Kashmiri Muslims or the high-caste South Indian Brahmins who look after the shrine at Paśupati, do not now identify themselves as Newars even though they speak the language and follow the social rules that other Newars do (Gellner and Quigley 1999). Newar social organization finds its natural scale in the guthi, an endowed association that often combines locality, caste, and lineage membership (Toffin 2005). Many guthis are funeral cooperatives. Others with more heterogeneous membership exist for pilgrimages, religious rituals, heritage preservation, or to look after specific shrines. An oft-repeated Newar definition of a Newar is 'someone who speaks Newari and belongs to a guthi'

In the 1760s when the Gorkhali kings overran the central Himalayas and created their empire, the dynamic and complex Newar civilization was reduced at a stroke of the sword to a subject population, treated as largely homogenous and profoundly inferior in the legal and cultural norms of the new state of Nepal (Hofer 1979). This military and political subjugation, brutally enforced, defined the Newars as an Indigenous community who slowly developed a sense of themselves as a single ethnicity (Gellner 1986, 1991; Gellner et al. 1997; Quigley 1987). Across the nineteenth century, Newars reacted to subjugation: they reinforced their transnational connections in Tibet and India and established new regional trading centers across the central Himalayas. Newar language printing emerged in India, to the fury of the Gorkhali rulers, and Newar poets and activists in Nepal were imprisoned or exiled. In the 1960s, after the closure of Tibet and the opening up of Nepal, Newars began to emigrate. There are now important Newar transnational communities around San Francisco, Boston, London, and Sydney, and many smaller diaspora communities elsewhere. In diaspora, the guthi has become a structure through which Newars build regional associations for the performance of rituals and the preservation of language. At the same time, the country of Nepal is still firmly controlled by caste hill Hindu elites (see below), to the detriment of Newars and many other Indigenous communities who make up about a third of the population of modern Nepal. 
Newar women, although they grow up in a nominally virilocal society, have extraordinary freedom compared to other women in Nepal. As part of growing up they undergo ritual marriages to powerful beings, such that their eventual marriage to a man is only their most recent. Unlike almost all other women in Asia, Newar women thus have the free right of divorce and suffer no stigma of widowhood. Moreover, although Newar women usually move to their husband's father's home on marriage, they and their families must return to her home for many rituals. Women retain strong connections to their brothers-who are necessary participants in their children's life cycle rituals-as well as to their own mother's brother (Gellner 1991; Gutschow and Michaels 2008; compare to Bennett 1983)

From all this it will be gathered that our marriage cannot easily be described as marrying in or marrying out. Will became a jillaju, a son-in-law, an advocate, and scientist working with and for specific Newar lineages and communities. Sometimes he counts as Newar, and sometimes he doesn't. Bhāvanā might have married out and disappeared if she were not a committed and occasionally pugnacious Newar cultural activist who found an ally and a partner when she married-but marrying out is complicated for a Newar woman in Gorkhali Nepal. Newar women are remarkably powerful but the deeply patriarchal structure of Nepalese law means that neither she nor her children will ever have the same legal rights in the Newar homeland as her brother's children will: they cannot have a Nepalese passport, own property, or inherit from her father. Every negotiation for a residency visa, a business license, or a tax document exposes her to a stream of bluntly racist and sexist commentary from officials, along with incessant demands for exorbitant bribes. Indeed, the first time we tried to fly from Nepal to the United Kingdom together in 2003, Bhavana was stopped by airport officials as, under Nepalese law, no unmarried woman under the age of 35 could leave Nepal without her father's permission.

Children born in Newar families become fully Newar adults through a sequence of grounded social rituals that weave them into lineages connected to places, deities, manners and obligations (Lewis 1994). By deliberately preserving Bhavana's lineage name (Tuladhar), by using the language with our children and teaching them manners, by performing all the appropriate coming-of-age rituals for each of our children, through sponsoring traditional Vajrācārya Buddhist priests to perform some of those rituals, and through observing the appropriate annual rituals, we have become a diaspora Newar family with passionately felt roots in the Kathmandu Valley. We consulted with several generations of Bhavana's relatives before taking on the name Tuladhar. Each of the children has a proper Newar Sanskrit Buddhist name alongside their Western name, so that they can do rituals as nameable people and can be named in ritual documents. Our children speak and understand Newari, hear Newar Buddhist stories at bedtime, and are strongly connected to their mother's family and various shrines in Pharping and Kathmandu. Where it has been possible we have gone back to Nepal for rituals. In 2007, we sponsored a lengthy ritual in Nepal that defined our home in Aberdeen as a place where it was possible to perform rituals correctly. And when it is impossible, we have jointly pored over ritual texts and memories to find some proper way to wake up the landscape and fill it with the Bodhisattvas and protectors who will look after our family. We watched, helpless, as the 2015 earthquake destroyed shines we knew and loved, and we were unable to be there to respond to the immediate tragedy or the subsequent scandalous corruption. And we carry on, listening to the recordings from our fieldwork, asking elders for help through Facebook or email, taking turns making the tea and coffee while trying to make sense of a manuscript, staying up late with the children explaining, again, why it's okay for them to dodge awkward questions about Newar identity or rituals in class sometimes but they must never, ever forget who they really are.

\section{The Category of Indigenous in Nepal and Scotland}

The claim that Newars in general, or Tuladhars as a special kind of Newar, are Indigenous is a claim to a certain privileged status on the world stage, made within a context of oppression, violence, and struggles for constitutional recognition in the modern state of Nepal as well as a millennia-long history of dwelling in the region around what is now the Kathmandu Valley. This claim is based both on political oppression and on ecological ethnicity, two criteria among a shifting set that recur in attempts to define or negotiate the term 'Indigenous' (Cadena and Starn 2007; Corntassel 2003; Gomes 2013; Parajuli 1998; Postero 2013). Tsing captures the peculiarity of this term: 'promising contradictions' of 'authenticity and invention, 
subsistence and wealth, traditional knowledge and new technologies, territory and diaspora' (Tsing 2007:33). Corntassel reminds us that "The dilemma over "who is indigenous" has become increasingly politicized as indigenous peoples have attained a distinct legal standing under international law' (Corntassel 2003:76). This journal capitalizes the word 'Indigenous' as a mark of respect-and, perhaps, as a way of signifying and asserting ethnobiology's own cheerfully hybrid disciplinary relationship with Indigenous and local peoples. That should not be mistaken for an essentialist claim that Indigenous is the same everywhere, nor that the term Indigenous exhausts the kinds of community who also deserve that respect. De la Cadena and Starn (2007:4) note that

...indigeneity emerges only within larger social fields of difference and sameness; it acquires its "positive" meaning not from some essential properties of its own, but through its relation to what it is not, to what it exceeds or lacks. ... indigenous cultural practices, institutions, and politics become such in articulation with what is not considered indigenous within the particular social formation where they exist. Indigeneity, in other words, is at once historically contingent and encompassing of the nonindigenous - and thus never about untouched reality.

That relationality is challenged and balanced by a deep connection to place/territory/country that is utterly specific to each Indigenous community, asserted by Corntassel thus: 'a close relationship with their ancestral homelands/sacred sites, which may be threatened by ongoing military, economic or political encroachment or may be places where indigenous peoples have been previously expelled, while seeking to enhance their cultural, political and economic autonomy' (Corntassel 2003:92). Parajuli was one of the first theorists to link Indigenous stewardship of place to political disenfranchisement and coined the term 'ecological ethnicity' to capture the connection (Parajuli 1998). Attachment to place includes the mobile experience of nomads and transhumant pastoralists (omitted by Parajuli), communities that are among the first to be denied access to their places by nation-states and landlords.

The particular claim that Tuladhars, as Newars, are Indigenous is one of many jostling in a red-hot
Himalayan mesh of other claims about ethnicity, religion, language, culture, history and ecology, some of which see Newars as complicit in oppression, and some of which set different segments of Newar society against each other (for a survey of Newar castes, see Gellner and Quigley 1999). For Tuladhars, even the sense of dwelling is problematic. Among Newars, many subgroups such as Jyapu or Balami are sedentary agriculturalists, but Tuladhars have always been transnational caravaneers building trade routes and bazaars across Asia, adapting to shifting economies, legal regimes and boundaries, whilst deeply tethered through rituals and kinship to just one Newar city, Kathmandu 4 . Hence the models of sedentarism, nomadism or transhumance cannot capture how Tuladhars inhabit and create place.

It is not just that the term Indigenous is deployed in varying contexts; theorizing about indigeneity must also be historically and geographically contextualized. Much of the theory put forward by Indigenous scholars is written in a specific kind of postcolonial context, usually in the Americas, Australia or Oceania 5 . In Asia, colonization was never only perpetrated by outsiders from Europe. Most Asian states portray themselves as former colonies, not as colonizers or settler states. Nonetheless, many countries such as Bangladesh, Taiwan, China, and East Timor can list both European and Asian colonial powers among their prior oppressors; while Thailand and Nepal, both countries with significant Indigenous communities, proudly identify themselves as never having been colonized. These histories are used to produce academic policies and theoretical regimes that distinguish national identities. For example, the category of Indigenous exists, with legal backing and academic institutions to support it, in Taiwan. The 2007 Basic Law for Indigenous Peoples has the 'ultimate goal of establishing parallel 'nationhood' institutions in legislation, judiciary, education, and so on among indigenous communities' (Huang and Liu 2016). By contrast, in the People's Republic of China all citizens belong to one or another nationality, even though the Han are explicitly recognized as having a superior and civilizing role to play, and the term Indigenous is discouraged.

This variety of political, environmental, and theoretical contexts poses an interesting challenge for Tuladhars theorizing their own status: a Tuladhar family, up until 1960, would typically have had permanent shopfronts and warehouses in Tibet, 
Nepal and India. In our own family, there are cousins who have been, since 1960, of Tibetan nationality with Chinese citizenship. While diaspora kinship is now a shared experience for many Indigenous communities, it is not an acquired but an original feature of Tuladhars as Indigenous. In contrast to Clifford's formulation of a tension between autocthony and diaspora (2007:205), Tuladhars have always inhabited a complex landscape: ancestral homes in a Kathmandu which is more ancient and original that the Nepalese state that conquered it; shops and homes in other bazaars across what have only in the past decades become Nepal, China, and India; perilous passages in between; and constant communication among all those.

For us, then, living outside Nepal as one link in a transnational extended family, Tuladhar kinship both generates a sense of separation from the sacred geography of Kathmandu and furnishes a set of strategies that Tuladhars have always used to manage that separation. We do not teach our children to be Indigenous: we teach them that they are Tuladhars (and also, as it happens, Douglases). The rights and responsibilities to undertake rituals, kinship, manners, language, deportment, gendering and many other disciplines of body, speech and mind which we try to exemplify and transmit to them flow from being Tuladhars. It is only when someone outside asks, 'What is Tuladhar?' that we teach them to invoke the term 'Indigenous' in order to explain, using cosmopolitan categories, why it is that we don't blow out candles, or do speak to each other using a different language, and all the other differences. Some of those differences are carried over from how Tuladhars behave in Nepal, and some are part of the toolkit of transnational Tuladhars, and some of them are our own improvisations crafted together with the children in response to the Scottish context where we now live.

Ernest Gellner called Nepal a 'conquest empire' (Gellner 1978), a state that was created when one petty kingdom conquered many other regional polities. While there are long conversations about imperialism and post-colonialism in Asia, we do well to remember that many modern Asian states are the descendants of successful Asian empires, structurally and historically determined by the subjugation of Indigenous peoples. Nepal is dominated by the caste hill Hindu elites (hereafter CHHE) (Lawoti 2008:366). As Lawoti shows, the effect of democracy since 1990 has actually been to further marginalize Indigenous communities while shifting the balance of power between two elite castes, from the Chetri (ideally kings, and traditionally connected to the old palace elite) to the Bahun (ideally priests, now party leaders of every political party).

Scotland itself is a contested field. Scotland's own history locates it both as successfully resisting English rule and as participating in the British colonial project. In recent referenda showed that almost half the population voted for independence from the rest of the United Kingdom and a substantial majority voted (against the rest of the United Kingdom) to remain part of Europe. In the years leading up to the independence referendum of 2014, a vision of Scotland as a welcoming and egalitarian nation emerged, and this vision appealed strongly to many immigrants from Asia. Research done by Will for the Royal Society of Edinburgh in 2010 showed that immigrants from Sri Lanka and Thailand had a strongly positive view of Scottish Government. This view was explained by Asian immigrants as deriving from an immigration program initiated by the Scottish Government that encouraged international students finishing any higher degree to stay in the country to look for skilled work, but Asian immigrants also perceived the Scottish Government as making great efforts to extend the social welfare net to immigrant families. By contrast the United Kingdom government was identified with dawn raids by the immigration authorities, who sent undocumented immigrants to detention facilities and then deported them ${ }^{6}$. This optimistic view of Scotland connects to the divided opinions of the non-immigrant community. Xenophobia and hostility to immigrants is very strong among those Scots who voted against independence and for Brexit, while pro-independence and antiBrexit voters still call for an inclusive and diverse society.

Neither the United Kingdom nor Scotland has any legal protection in place for Indigenous communities as part of anti-discrimination laws. This is doubly ironic, given that England was one of the great colonial powers and that Scots have reflected long and hard on their complicity-and-oppression through the colonial period, especially after the Acts of Union in 1707 (Calloway 2008). Many Anglophone former colonies do have some legislation and even treaties governing their relationship with the Indigenous communities that dwelled in the 
landscapes that colonists appropriated. Both in Scotland and in Canada we have spoken with First Nations scholars and activists who are proud of their Scottish ancestry.

Yet the term 'Indigenous' is toxic in Scotland's own debates. Used with respect to the Scottish situation, it evokes right-wing, white, anti-immigrant nationalist networks such as the English Defence League. On occasion, we have encountered research students from Eastern Europe who subscribed to racialist theories about pure Scottish blood-both historically and politically a terrible mistake. So unreflective is the conversation here that otherwise well-intentioned colleagues assert that because they are British, they are Indigenous. Bhavana's experience in public situations is that she is identified as Asian and has to manage misperceptions and sometimes abuse as an Asian person 7 . Only afterwards might there be an opportunity to assert her Indigenous identity, and it involves quite a bit of explaining. We have come to call this 'double discrimination'. It should not be surprising, then, that some of our challenges come at the interface with institutions, including the city of Aberdeen and the University of Aberdeen.

In Scotland, the perception of Nepal is as a romantic destination for adventure tourists and the source of the Gurkha regiments; from a university perspective, it's a niche market for international recruitment. As with many diaspora communities, elite Nepalese outside Nepal are often able to capture the diversity agenda in their new countries while simultaneously suppressing subaltern voices. A widely recognized, but little addressed, problem in education and policy around diversity in Scotland is that the identification of diversity stops at the level of nationality. Problems of inequality and oppression in countries of origin are largely ignored. There is almost no discussion of Indigenous peoples whether from regions which are popularly perceived to have Indigenous communities such as Brazil or Australia, or from Asian countries where the internal oppression of Indigenous communities is so thoroughly established that it appears seamless and untroubling to the outside world. This lack of recognition is apparent to all sides in the diaspora community and facilitates the oppression of Indigenous folk even in diaspora. Aberdeen, traditionally conservative and remote, was never a destination for Commonwealth immigration. However, because of the oil industry and EU mobility, there are now a number of immigrant communities and the region is still struggling to adapt. As a result of ex-Gurkha settlements as well as university recruitment through CHHE networks, there is a complex Nepalese community in Aberdeen. The diversity agenda at the city level was quickly colonized by caste hill Hindu elites, who were able to establish an official Nepalese and Himalayan Association' in 2005, recognized by the city, that consisted entirely of CHHE families.

During 2015, our daughter's final year in primary school, all parents were invited to come along for a meeting run by the city council about governance and support for diversity at her school. Bhavana went along, curious to see what would be presented. The meeting began with an introduction to the parents' council and the city diversity programs. After that, representatives spoke about specific communities in Aberdeen and what each community was doing to protect their culture and language. There was a scheduled presentation from a CHHE parent at the school who spoke at length on behalf of, and about, the Nepalese community in Aberdeen. He described how the Nepalese association had been putting great effort into protecting Nepalese culture and Nepalese language and described the city's support for Hindu rituals and the Nepali language. Once he was finished with his talk, Bhavana stood up and, very carefully, pointed out that the Nepali speaking community in Aberdeen was not representative of Nepal. They did not support Indigenous languages or celebrate any Indigenous rituals. She mentioned that some of the ex -Gurkha Gurung families had said that they felt as though they were still in Nepal-oppressed-even though they were actually in Scotland, and that they had worked around the city-sponsored association to build networks with other Gurungs to support their culture. "All of our Indigenous cultures and our languages were excluded", she argued. She said that she was nonetheless glad that her daughter was in Scotland and at this school because we were freely able to speak and write our language at home and in the street, we had Newar guthis here, and we had the support of the school to represent Newar culture to the other students in our daughter's class.

When the meeting was over, the representative of the official Nepalese society followed Bhavana into the school yard. He was frustrated, and spoke with a fixed smile in Nepali to ensure that others could not understand his words or intentions. He challenged 
Bhavana: why did she care at all about Indigenous languages? He told her that she should not care about Indigenous languages or culture. He gave her an example from Scottish schools. Pointing at our daughter's school, he said, "You should look at these Scottish schools. Scottish people do not teach their children in Scots, do they? Everything is taught in English; you see my point?" He went on: "Our Nepali language was inherently religious and pure. It is related to the Sanskrit language. We Bahuns are the highest caste and are pure like the Sanskrit language. Scottish people may speak their language in their homes or with their friends but in school the Scots language has no value. Thus, languages other than Nepali are also not important"8. Looking straight into her eye he said, "You should not ask these Scottish people to help protect Newar culture and languagethese people whose own language and culture were under English dominion could not help and did not care."

He made his point. What is remarkable about this incident is not just the venom showed by the CHHE representative, but their cynical appropriation of United Kingdom politics to present Indigenous immigrants in Scotland as doubly subjugated. Precisely because policies around discrimination in Scotland-whether at the level of the city or, indeed, the university - stop at the national level, elites from Nepal can mobilize the structures of United Kingdom politics to replicate their privilege at the expense of others. Although the European Court of Human Rights does not have a good track record on Indigenous rights (Gismondi 2016; Kovacs 2015), it is at least some recourse. With the looming threat of Brexit, racist incidents in general are on the rise in the United Kingdom and unless Scotland can find a way to remain in the European Union it is likely that the legal and social disenfranchisement of Indigenous immigrants in Scotland will get significantly worse over the next decade. While we have always been active members of our school's community, and work closely with the head teacher and others, they were surprised by the exchange we report above.

Our daughter has moved on to secondary school and now our middle son is at that same school. Compared to other Indigenous communities, even among Newars, Tuladhars are mobile and transnational. Facebook discussion among Tuladhars often involve 20th century photos from Lhasa or Darjeeling (as well as Kathmandu)-discussions which involve participants in Australia, the United States, Europe, and Japan. This inherent mobility does give Tuladhars a power, at least conceptually, to escape from the confines of oppression by a single state. Inasmuch as the term Indigenous is deployed against a state in the hope of international status, Tuladhars can choose their identity as transnational caravaneers as an alternative to the term Indigenous. We do not know how our children will position themselves, though we can provide them with resources. We do know, from them, that when the term Indigenous is used in classes it is associated with stereotypes of hunter-gatherers in tropical jungles and they are unwilling to identify themselves as Indigenous in that context.

Fortunately, Tuladhars have a strong inventory of children's culture: there is a special range of Newar language that one speaks with children, and a considerable inventory of children's games-games with string, with seeds, with counters, and hand games. One of the simplest is called 'myala byān', 'fish or frog', and it's a game in which one person slowly waves an extended index finger in front of another, saying nyala nyalā... When the other player goes to grab the index finger, the first player quickly substitutes a thumb in order to trick their opponent into grabbing the thumb instead—saying byañ! We began to play this game with our son in the queue before school, and soon other children took it up. It has become something that only his class knows how to do: in the morning queue of restless children, one child will hold up a tantalizing finger and say nyäla nyäla and soon half the queue is trying to catch fingers. That has led to any number of questions: What is your language called again? Can you see Mount Everest from your house? How high up is his grandfather's home? What's the word for bird? Other languages come out, Igbo or Shona or Filipino or Polish, and recognition that this is the same language in which we bid him 'stay

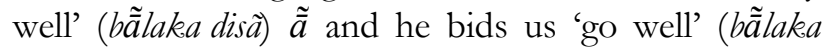
jhāsa $)$ when he goes into class. His class has been immunized against the kind of discrimination that Bhavana endured in that same playground. While this is not an answer to the systematic problems that confronted Bhavana that day, it is a constructive response. The elements of identification are language and games, aspects of culture, and do not require our son to label himself as Indigenous or take sides in a debate about janajäti politics in Nepal that may never actually concern him. 


\section{Taking Sides}

For Will, the obligations of kinship sometimes mean choosing sides between academic colleagues and Newar activists. Newar lineages transmit, among many other things, the oldest surviving tradition of Sanskrit Buddhism (and Tuladhars are staunch Buddhists). The manuscript collections held in scholarly families are of tremendous significance for the study of ancient as well as modern South and Central Asian ritual, medicine, philosophy and history. Indeed, for many scholars the only interesting thing about Newars is their manuscripts; contemporary rituals, writing, innovations and the contemporary scholarly community are ignored. Will has spent many years reading and using these manuscripts together with Newar scholars and Buddhist priests, in Sanskrit and in modern or older forms of Newari. Since the late 1990s, he has been involved in various discussions about how to encode the distinctive Newar writing system called Newa Lipi within Unicode. Newar cultural activists have argued that any Unicode implementation of Newa Lipi must treat distinctively Newar breathy consonants (such as mba and $t h a$ ) not as conjuncts, but as single sounds. Looked at from the perspective of printing on a page or a screen, this is a pointless distinction; but for Newar cultural activists, it matters that sounds found in Newari but not in Indo-Aryan languages like Sanskrit or Nepali are treated as first-order items. A comparable question would be whether it is acceptable to treat ' $w$ ' as just two ' $v$ ' characters in writing English, or if it needs its own representation as a letter. Icelandic retains the character $\mathrm{D}$ for a 'th' sound shared with English, but modern English has lost this glyph and uses two characters to write the single sound.

In 2014, progress was being made at last towards realizing a Unicode standard for the Newari script. However, a meeting between key Newar scholars and a font programmer who had worked on other South Asian scripts broke down acrimoniously. Will received an email from Western colleagues asking him to please urge the various Newar factions to accept the programmer's proposals. He responded with a long email, defending the right of Newar activists to disagree with each other and outsiders about their script, including the following:

no technology is neutral: all technologies encode and reproduce power relations and cultural assumptions. You could read Ivan
Illich, or Foucault, or even my own articles on this. The Unicode standard is no different. What is at stake here is the integrity and dignity of Indigenous knowledge. It would be boring, but easy, for me to list the reasons why it matters very, very much to Newars in particular that they control the way in which their civilization is represented. In the past century, people have been beaten, imprisoned, exiled and died for using these scripts—not just people, my own children's uncles and aunts.

Another colleague then replied, saying:

It's fine by me if some people self-identifying as Newars want to discuss the script indefinitely; that's a wonderful luxury. The problem for others is that the script is not their sole business and never will be. It's a vehicle for Sanskrit, Maithili, Tibetan. It's so much more than a racially delimited construct.

In reply, Will quoted from the UN Declaration on the Rights of Indigenous Peoples (UNDRIP), Article 13:

Indigenous peoples have the right to revitalize, use, develop and transmit to future generations their histories, languages, oral traditions, philosophies, writing systems and literatures (emphasis added)

Through this testy exchange, Will put himself firmly on the side of Newar scholars and activists, and against one group of academic colleagues. As is clear from the exchange, some philologists do not accept the validity of 'Indigenous' as a category for Newars, nor the right of Newars to their own transmitted knowledge, nor the right of Newars to decide who are their kin. The ethical framework for ethnobiology, as also UNDRIP, strongly asserts the sovereign right of an Indigenous community to do as they wish with their knowledge and to determine their own membership; but actually endorsing that position and siding with one's adopting Indigenous community means accepting that one's academic reputation will change irrevocably. The gaps in values and understanding here are not, actually, best analyzed in terms of Indigenous and non-Indigenous. Rather, they are between philological approaches to texts as disembodied universals that happen to find material form in more or less convenient vehicles, and sociological approaches that analyze the inscribed power of writing, memory, copying, recitation and so 
forth that constitute a text as an historically situated event; between colonial approaches to discovered texts that need rescue, protection and decipherment and post-colonial approaches that aspire to read with (but not at or for) those who steward a living recitation and copying tradition; and between globalizing technologies of encoding that render the text legible and kinship relations to inherited knowledge practices that generate meaning.

We observed that the lack of recognition for Indigenous people is a serious challenge in dealing with the city of Aberdeen and/or the city schools. The University of Aberdeen has a similar blind spot; although it has an excellent collection of anthropologists scattered across three schools, the university's own policies on diversity are haphazard and poorly implemented. Like many neoliberal universities, university management prefers to buy prepackaged diversity training courses, rather than engage with the potentially challenging expertise of their own academic staff. It is no surprise that there is no recognition of Indigenous peoples in the administrative processes of the university.

In August 2015, not long after the Nepal earthquake, Will received one of the highest honors that a foreign scholar of Newar culture can receive. For well over two decades of careful research into Newar language, history and culture, he was awarded a Hanapau from the cultural network Matina. He and our daughter travelled to London, where our daughter won an award for singing a traditional Newar song accapella, and Will gave a rather boring speech in Newari. He regards it as the highest honor he is ever likely to receive, and when he was told that he might be given the award he began to work with the university's public relations office on publicizing the award. In the United Kingdom publicity is one metric of research effectiveness - a feature of audit cultureand academics and their universities often seek different goals through publicizing the same event. In this case, we felt the award could be a powerful tool for highlighting the disproportionate effect of the devastating 2015 earthquake on Newar and Tamang settlements and monuments, a proposal which the Matina award committee endorsed. In that same month, he had been appointed director of the university's Confucius Institute. Colleagues in China were delighted by Yuan dynasty and Silk Road connections to Newar scholars, merchants, priests and artists, and were deeply concerned about the earthquake. First local officials along the border, and eventually the central Chinese government, had mobilized a great deal of effective aid for communities in Nepal in the immediate aftermath of the earthquake, and were well aware that Indigenous mountain communities had ben disproportionately affected. Yet in Aberdeen, the university public relations office was afraid that a story about Indigenous communities might offend the Chinese government ${ }^{9}$. In this case, the universal and globalized category of Indigenous occluded important differences. No announcement was ever made.

\section{Learning to be Gatekeepers}

We often work together training students in theory, Himalayan area studies, research methods and language skills. Will was invited to join a research network some years ago, and to help supervise a promising $\mathrm{PhD}$ student, who soon began to work with both of us. After several months of training this student, it was agreed that they should make an initial trip to Nepal to explore their possible fieldwork site. We made arrangements through a business owned by Bhavana's family and negotiated with family and friends to set up the best possible initial trip, on the firm understanding that this student would not actually undertake interviews or fieldwork as they had not established a protocol with any community of informants. We worked through our network of contacts to find elders who might work with them if they conducted themselves well on this first trip. The student had not submitted any research ethics approval paperwork, had no Free and Prior Informed Consent (FPIC) paperwork, and had agreed on the clearest possible terms that they were simply going out to get a feel for the landscape and have a look at some communities where they might later return to establish a proper research agreement and conduct research.

Late in the arrangements, a second $\mathrm{PhD}$ student on the same research network attached themselves to the field trip. This student had not been trained by us, and had no training in ethnobiological research methods, protocols or ethics. There was nothing we could do to prevent this student from going along, but they refused to attend any of the pre-trip training. As this student had a background in bioprospecting but no experience working with Indigenous or local communities we felt unease. Within hours of reaching Nepal the phone calls began: the students were acting like imperial collectors. They had pressured our own 
family members and forced their way into our own research sites. We were told that they were shouting at informants, accusing them of hiding information, and demanding to know the ingredients for traditional medicines. We immediately rang all our informants and extended family and warned them that there was trouble. The situation went steadily downhill from there: even after being warned directly, they insisted on collecting samples without permission from the Nepalese government, insisted on conducting interviews with no prior protocols in place, and caused shock and anger across several Indigenous communities. The $\mathrm{PhD}$ student we had trained on cultural sensitivity turned our training upside down: they barged uninvited into kitchens and asked for names and samples of ingredients. The elders who were watching them reported their behavior to us, and we apologized endlessly for having created such a mess. The interloping $\mathrm{PhD}$ student staged an extremely public row with the owners of a hotel we knew well, and it was only through arranging a substantial bribe on the spot that a relative was able to keep the student out of prison. On their return, the sponsoring university initially refused to pay for the cost of the expedition and we had to resort to lawyers to recover as much of the costs as we could. It seemed to us that we had been used, not just by the research students, but by other researchers in the network who suspected we had unusual access to important networks of knowledge and had instructed their students to use us.

This was not the only time we had misjudged enthusiastic students, but this time it caused anger and embarrassment across a broad network of kin and colleagues. Since then, we have strictly separated our research from training research students, who now work in other places such as Scotland or China. If this essay reads as a somewhat grim catalogue of errors, it is in part because we are still learning how to be wise gatekeepers.

\section{Muddling Through}

With those select cautionary tales in hand it is clear that the play of kinship gives us rituals, games, food, manners and so much more, along with a tremendously rich research field; but it also imposes vulnerabilities and limits. Neither the simple civilities of life-such as the hope that one will escape discrimination and abuse-nor the complexities of academic life_-such as being able to publish copiously, attract enthusiastic students, and depend on one's university to demonstrate the relevance of critical research-are provided through this kind of partnership. At every turn, we review our research and our data to make sure we are not exposing anything we have promised to keep hidden, and we consult with each other to be sure that what we submit for publication will support our elders, informants, teachers, colleagues and children. Work proceeds slowly, and often doesn't fit well with disciplinary expectations. We endure criticism from some scholars within the Newar community, because what we do publish often doesn't suit their political agendas or personal ambitions. In return, though, we have been honored to be asked to undertake genuinely important research, and that has found funding from sympathetic funding bodies. Another story is in order.

In 2006-2007, we had a small amount of funding to study the use of bats as medicine among Newars. During this research, Will was told repeatedly by Newar informants who used traditional medicine to interview a specific community of traditional pharmacists; when he finally worked out who they were, he realized that the community already knew him, and were not-so-distant relatives of Bhavana. This most extraordinary community are the Bania, who have managed the trade networks in materia medica across the Himalayas and much of Asia for at least a thousand years, and have managed to keep out of the political spotlight and yet close to the centers of power for two hundred years so as to get on with its business. After a series of initial conversations, the Bania formally requested us to write their history. It took years to get funding for the project, but from 2010-13, we were able to work with the Bania and track their trade and medical networks across three hundred years and many long trails. Doing this required all our skills, and we are patiently continuing the research and writing up the results into a substantial two-volume monograph in English and Newari.

This project was an unusual choice for a Western funder, in this case the Wellcome Trust, because the framework for the project came from the community itself $^{10}$. Once we had the funding, we worked with two senior members of the community to request a meeting of the guthi in order to review our plans and secure approval. Amrit Man Singh Bania, a professor of botany, agreed to co-author the monograph with us on the understanding that we include, and exclude, specific material from the final volumes. The Bania 
elders asked for specific chapters and specific confidentialities. As we settled into the project, it became clear that our unusual position as a partnership and a family offered them a mix of skills, sensitivities and vulnerabilities-our children became very fond of their sweets, and between polyglot marketplaces and ancient manuscripts, we found our language and research skills sorely exercised. It was very clear that we were trusted to recognize and manage awkward social facts that were brought to the surface because of our research. At times, when stories came flowing out hotly debated between two rival storytellers, it took both of us and two recorders to make sense of what we were hearing. At times, a swift kick under the table made it clear that the conversation had strayed into sensitive territory and further questions were inappropriate. It helped that Bhavana shared the nuances of elegant Urāy Newari with the Bania, but also helped that we were clearly both constrained by a sometimes awkward bond of kinship to them; and it definitely helped that between the two of us we could usually track down obscure terms across the half-dozen languages that Bania routinely use. The fieldwork happened in shops, on trails, in busses and cafes, sometimes with the Bania themselves and sometimes with the collectors and middlemen whose networks the Bania expertly steward. Although we wish we had been able to produce the monograph very soon after the end of fieldwork, we also know that to honor the trust and investment of the Bania, we have to do it right.

There was a day, well up the side of a steep mountain, when we fell to talking about identity. Our party included Bhavana's father, Bhavana, Will, and two of our children, one still in a baby backpack. We were walking with AMG, a veteran collector and trader in medicinal herbs, and OP, a remarkable local collector who, others said, had been suckled by the mountain itself, as well as a cook and eight porters. We fell to discussing the economics of expeditions and trekking. AMG pointed at a stone and said, Now that stone, that stone is authentic and organic.' Every single one of us, if you cared to pick at the details, was dodgy - questionable parentage, a business that had a reputation for smuggling and fraud, a whole trekking party of people whose economic survival depended on the construction of knowledge as authentic. This comment paralyzed us with laughter and cracked open a cornucopia of authenticity: for the rest of the trip, we ate only authentic and organic packet noodles, spoke only authentic and organic words, and removed genuinely authentic and organic leeches from our legs.

That moment has, for us, come to stand for the playfulness of family research, as well as the obstacles and vulnerabilities we face. Visitors to Nepal, whether anthropologists, tourists, or international agencies are constantly seeking a retreating image of authentic and natural places and people, and that elusive desire powers a complex economy that creates many livelihoods. For an anthropologist authenticity is won through the rituals of fieldwork, but its value is only realized through objectifying institutions of higher education and publication. As a hybrid and transnational household working at ethnobiology within an Indigenous family, we straddle those two processes. In addition to a sustainable livelihood and academic reputation, the value we seek to create is constrained and generated by a third gap, the gap between rights and responsibilities ${ }^{11}$.

We two parents in our household both have the responsibility to research, steward, adapt and transmit Newar rituals, knowledge, values and practices from parents and elders to our children, and we are teaching our children to accept and uphold that same responsibility. Yet between Bhavana and Will, Bhavana alone has the right to decide whether to expose those practices and knowledge to a wider community as part of our work. While marrying into an Indigenous family may, if that family chooses, assign responsibility for knowledge, values and practices to the in-married spouse, it does not in any way convey rights to the control or dissemination of that knowledge. If research and publication or teaching-or any other form of commodifying culture, such as selling works of art-is a source of income for that new household, then clear communication in both languages and absolute respect for prohibitions or subtler boundaries are vital. At the same time, the possibilities for new kinds of collaboration and adaptation soar beyond the ethical foundations on which such a marriage must be built.

\section{Notes}

${ }^{1}$ For other anthropologists who have not been welded through the rituals of marriage, it might also point to discussions of how anthropologists are located in their host societies by virtue of the social location of their actual host families; and in the Nepalese case, it certainly points towards the literature on fictive kinship (mit) and on adopting outsiders through 
Younger Brother worship (Messerschmidt 1982). But we are married with children, and the difference is that there is no longer one outsider connected to a community (a 'leaf node'), but the constant responsibility of colluding to transmit culture up and down the family ('circulation through the growing trunk').

${ }^{2}$ This set of food offerings is called saga and, with minor variations, is also used at other rituals. See Gellner (2003).

${ }^{3}$ Compare Baumann's study of birthday rituals among South Asian immigrants in London (1992).

${ }^{4} \mathrm{~A}$ number of histories and ethnographies document Tuladhar families, including a number of works by Todd Lewis (e.g., Lewis 1984, 1993); but the most powerful expression of this polytopy is the novella The Letter That Would Not Burn by a Tuladhar writer, Chittadhar 'Hridaya' (Tuladhar and Lall 2002).

${ }^{5}$ The 2007 volume Indigenous Experience Today, arising from a Wenner-Gren symposium, draws on a number of sites in Asia and Africa to helpfully challenge many assumptions.

${ }^{6}$ The Nepalese community, which is relatively small, was the only Asian immigrant community in Scotland that voted against independence, as became clear to us through discussions and social media at the time. This may be because the Nepalese migration to the United Kingdom was ex-Gurkha soldiers; both Nepalese immigrants and British citizens use the Gurkhas as a way to explain Nepalese presence in the United Kingdom.

${ }^{7}$ This is comparable to the experience of British Hindus, who have adopted the label 'British Hindu' in order to distinguish themselves from 'British Asians', which in Britain usually means Muslims of Pakistani origin or descent. See Ramji (2008) for a good discussion of gender, color and labelling in Britain.

${ }^{8}$ In fact there are a range of programs designed to encourage the use of Scots (in Northeast Scotland, Doric) or Gaelic in Scottish schools, but our particular school has a substantial immigrant population and directs its resources towards English for speakers of other languages.

'In 1993, the University of Aberdeen awarded an honorary doctorate of laws to the Dalai Lama. In 2005, after a complaint from a Chinese student, the photograph of that ceremony was removed from the university's offices but then reinstated (elsewhere) following protests.
${ }^{10}$ Research led by the community under study is an ideal enshrined in the code of ethics for ethnobiologists; but funding priorities in the United Kingdom are usually set by government agendas (for state funding bodies) or expert panels, or else is awarded to the proposals of individual academics. The Wellcome Trust, whose usual business is large-scale medical research, was remarkable in its approach to this grant.

${ }^{11}$ We thank Wiwik Dharmiasih for a useful discussion of this distinction at the World Conservation Union Working Group on Cultural and Spiritual Values of Nature conference, Vilm 2017.

\section{Declarations}

Permissions: None declared.

Sources of funding: Funding for research with the Bania was provided by a Wellcome Trust Medical Humanities grant (092720).

Conflicts of Interest: None declared.

\section{References Cited}

Ahmad, F. 2003. Still "in Progress?” — Methodological Dilemmas, Tensions and Contradictions in Theorizing South Asian Muslim Women. In South Asian Women in the Diaspora, edited by N. Puwar and P. Raghuram, pp. 43-65. Berg, Oxford, United Kingdom.

Austin, J. L., J. O. Urmson, and M. Sbisà, eds. 1975. How to Do Things with $W$ ords, $2^{\text {nd }}$ edition. Harvard University Press, Cambridge, MA.

Basso, K. H. 1996. Wisdom Sits in Places: Landscape and Language among the Western Apache. University of New Mexico Press, Albuquerque, NM.

Baumann, G. 1992. Ritual Implicates "Others": Rereading Durkheim in a Plural Society. In Understanding Rituals, edited by D. de Coppet, pp. 97-116. Routledge, London.

Cadena, M., and O. Starn, eds. 2007. Indigenous Experience Today. Berg, Oxford, United Kingdom.

Cadena, M., and O. Starn. 2007. Introduction. In Indigenous Experience Today, edited by M. Cadena and O. Starn, pp. 2-30. Berg, Oxford, United Kingdom.

Calloway, C. G. 2008. White People, Indians, and Highlanders: Tribal People and Colonial Encounters in Scotland and America. Oxford University Press, Oxford, United Kingdom. 
Clifford, J. 2007. Varieties of Indigenous Experience: Diasporas, Homelands, Sovereignties. In Indigenous Experience Today, edited by M. Cadena and O. Starn, pp. 197-223. Berg, Oxford, United Kingdom.

Corntassel, J. 2003. Who Is Indigenous? "Peoplehood" and Ethnonationalist Approaches to Rearticulating Indigenous Identity. Nationalism and Ethnic Politics 9:75-100.

Gaenszle, M., M. Turin, R. B. Chettri, and W. Tuladhar-Douglas. 2016. People. In Nepal. An Introduction to the Natural History, Ecology and the Human Environment in the Himalayas. Flora of Nepal. Royal Botanic Garden, Edinburgh, Scotland.

Gellner, D. N. 1986. Language, Caste, Religion and Territory: Newar Identity Ancient and Modern'. European Journal of Sociology 27:102-48.

Gellner, D. N. 1991. Hinduism, Tribalism and the Position of Women: The Problem of Newar Identity. Man 26:105-125

Gellner, D. N. 1993. Monk, Householder, and Tantric Priest: Newar Buddhism and Its Hierarcby of Ritual. Revised Indian edition. Cambridge Studies in Social and Cultural Anthropology 84. Foundation Books, New Delhi, India.

Gellner, D. N., J. Pfaff-Czarnecka, and J. Whelpton. 1997. Nationalism and Ethnicity in a Hindu Kingdom: The Politics of Culture in Contemporary Nepal. Harwood Academic Publishers, Amsterdam.

Gellner, D. N., and D. Quigley. 1999. Contested Hierarchies: A Collaborative Ethnology of Caste Among the Newars of the Kathmandu Valley, Nepal. Oxford University Press, Delhi, India.

Gellner, E. 1978. Myth and Reality in Nepal. Government and Opposition 13:127-129.

Gismondi, G. 2017. Denial of Justice: The Latest Indigenous Land Disputes Before the European Court of Human Rights and the Need for an Expansive Interpretation of Protocol 1. Yale Human Rights and Development Law Journal 18:1-58.

Gomes, A. 2013. Anthropology and the Politics of Indigeneity. Anthropological Forum 23:5-15.

Gutschow, N., and A. Michaels. 2008. Growing up: Hindu and Buddhist Initiation Rituals among Newar Children in Bhaktapur, Nepal. Otto Harrassowitz Verlag, Wiesbaden, Germany.

Höfer, A. 1979. The Caste Hierarchy and State in Nepal: A Study of the Muluki Ain of 1854. Universitätsver- lag Wagner, Innsbruck, Austria.

Huang, S., and S. Liu. 2016. Discrimination and Incorporation of Taiwanese Indigenous Austronesian Peoples. Asian Ethnicity 17:294-312.

Ingold, T. 2000. The Perception of the Environment: Essays on Livelihood, Dwelling, and Skill. Routledge, London.

Kimmerer, R. 2011. Restoration and Reciprocity: The Contributions of Traditional Ecological Knowledge. In Human Dimensions of Ecological Restoration, edited by D. Egan, E. E. Hjerpe, and J. Abrams, pp. 257-276. Island Press, Washington, DC.

Kovacs, P. 2015. Indigenous Issues under the European Convention of Human Rights, Reflected in an Inter-American Mirror. George W ashington International Law Revue 48:781-806.

Lawoti, M. 2008. Exclusionary Democratization in Nepal, 1990-2002. Democratization 15:363-385.

Lewis, T. T. 1984. The Tulādhars of Kathmandu: A Study of Buddhist Tradition in a Newar Merchant Community. Unpublished Doctoral Dissertation, Columbia University, New York.

Lewis, T. T. 1993. Newar-Tibetan Trade and the Domestication of Siṃhalasārthabāhu Avadāna. History of Religions 33:135-160.

Lewis, T. T. 1994. A Modern Guide for Mahāyāna Buddhist Life-Cycle Rites: The "Nepāl Jana Jivvan Kriyā Paddhati”. Indo-Iranian Journal 37:1-46.

Messerschmidt, D. A. 1982. Miteri in Nepal: Fictive Kin Ties That Bind. Kailash. A Journal of Himalayan Studies Katbmandu 9:5-43.

Parajuli, P. 1998. Beyond Capitalized Nature: Ecological Ethnicity as an Arena of Conflict in the Regime of Globalization. Ecumene 5:186-217.

Postero, N. 2013. Introduction: Negotiating Indigeneity. Latin American and Caribbean Ethnic Studies 8:107-121.

Quigley, D. 1987. Ethnicity without Nationalism: The Newars of Nepal. European Journal of Sociology 28:152-170.

Ramji, H. 2008. Exploring Commonality and Difference in In-Depth Interviewing: A CaseStudy of Researching British Asian Women. The British Journal of Sociology 59:99-116.

Toffin, G. 2005. From Kin to Caste: The Role of Guthis in Newar Society and Culture. Mahesh Chandra Regmi Lectures 3. Social Science Baha, Kathmandu, 
Nepal.

Tsing, A. 2007. Indigenous Voice. In Indigenous

Experience Today, edited by M. Cadena and O.
Starn, pp. 33-68. Berg, Oxford, United Kingdom.

Tuladhar, C. H., and K. Lall. 2002. Letter from a Lhasa Merchant to His Wife. Robin Books, New Delhi, India. 